\title{
Structural and Magnetic Properties of $\mathrm{Cu}(\mathrm{dpa}) \mathrm{X}_{2}$ (dpa = Di-(2-picolyl)amine; $\mathrm{X}=\mathrm{Cl}$ and $\mathrm{Br}$ )
}

\author{
Hong-Woo Lee, ${ }^{\dagger}$ Hoe-Joo Seo, ${ }^{\dagger}$ Hee-Jin Kim, ${ }^{\dagger}$ Sung Kwon Kang, ${ }^{\ddagger}$ Ji Youn Heo, ${ }^{\circ}$ and Young-Inn Kim \\ Deparment of Chemistry Education and Center for Plastic Information System, Pusan National Lniversity, \\ Pusan 609-735, Korea. E-mail: vikimapusanac.kr \\ ${ }^{\dagger}$ Department of Chemistry, Graduate School, Pusan Sational Lniversitv, Pusan 609-735, Korea \\ 'Department of Chemistry, Chungham National Lniversity, Daejeon 305-764, Korea \\ Received October 17, 2006
}

Key Words : 5-Coordinated copper(II) complex. Trigonal bipyramidal copper(II) complex. Di-(2-pycolyl)amine complex

Di-(2-picolyl)amine (dpa) can coordinate with transition metal ions through an amine nitrogen as well as two pyridine nitrogens and act as a tridentate ligand. The transition metal complexes with dpa or substituted-dpa ligand continue to be interest in many fields in chemistry. For example. carbohydrate-appended dpa metal complexes were suggested as potential inaging agents ${ }^{1}$ and sugar-pendant dpa $\mathrm{Cu}$ (II) complexes were used to regulate chirality on the copper coordinated oxygen atom. ${ }^{2, \hat{3}}$ Zinc-dpa complexes were applied to fluorescent chemsensors toward a phosphrorylated peptide surface. . $^{4 \cdot 6}$

Recently. the monomeric structure of copper chloride complexes with dpa. $\mathrm{Cu}(\mathrm{dpa}) \mathrm{Cl}$ : was reported by two

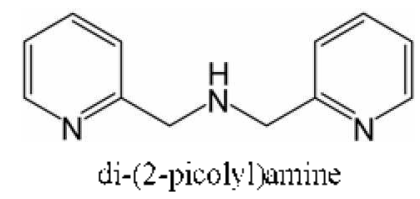

research groups ${ }^{7.8}$ to study on the $\mathrm{C} \cdot \mathrm{N}$ bond cleavage of carboxamide by coordination of a neutral tertiary carboxanide nitrogen atom. ${ }^{\mathrm{s}}$ But the packing modes of $\mathrm{Cu}(\mathrm{dpa}) \mathrm{Cl}$ : were not reported even if the packing network plays an important role in determining its properties in solid.

Herein we prepared $\mathrm{CuX}_{2}(\mathrm{X}=\mathrm{Cl}$. Br) conplexes with dpa ligand in methanol solution and their structures were deternined using $\mathrm{X}$-ray single crystal diffraction analysis method. We extended the study to examine the packing modes of the prepared compounds in the solid state and investigate the role of anine nitrogen whether it took part in the formation of the hydrogen bonding to make a low dimensional network. The magnetic and optical properties were also studied on the basis of the corresponding structures.

\section{Experimental Section}

Di-(2-picolyl)amine was obtained commercially from Aldrich Chemicals and used without further purification

$\mathrm{Cu}(\mathrm{dpa}) \mathrm{Cl}$ - was prepared from the direct reaction of di-(2picolyl)amine (dpa) with $\mathrm{CuCl}_{2}$. A solution of $\mathrm{CuCl}_{2}(0.5$ mmol) in $20 \mathrm{~mL}$ of absolute methanol was added dropwise to $20 \mathrm{~mL}$ of dpa $(0.5 \mathrm{mmol})$ absolute methanol solution. The resulting mixture was stirred overnight and then allowed to stand at room temperature. The blue block crystals were obtained by a slow evaporation method. The blue $\mathrm{Cu}(\mathrm{dpa}) \mathrm{Br}_{2}$ crystals were prepared by a similar method using $\mathrm{CuBr}_{2}$ Elemental analyses were perfonmed at the Korean Basic Science Center, and the results are listed below:

Anal. (\%) Calcd. for $\mathrm{Cu}(\mathrm{dpa}) \mathrm{Cl}_{2}$ : C, 43.19; H, 3.39; N, 12.59. Found: C. 43.12; H, 3.66; N. 12.32. Calcd. for Cu(dpa)Br: C. 34.10: H. 3.10: N. 9.94. Found: C, 34.12; H, 2.91; N, 9.91

The data for X-ray structure determination was collected on a CAD-4 diffractometer equipped with graplite monochromated Mo K $\alpha$ radiation $(\lambda=0.71073 \AA$ ) at $295 \mathrm{~K}$. The unit cell dimensions were determined on the basis of 25 reflections in the range of $11.40^{\circ}<\theta<12.52^{\circ}$. The data was collected by the $w / 2 \theta$ scan mode. All non-lydrogen atoms were found by the direct method and their parameters were refuned successfully by full matrix least-squares. $\mathrm{H}$ atoms were geometrically positioned and fixed. Empirical absorption corrections were applied to the intensity data for the prepared crystals by using $\psi /$-scans. The programs used to solve the structure and to refine the structure are as follows: SHELXS97 and SHELXL97: ${ }^{.9}$ Molecular graphics; Ortep-3 for windows. ${ }^{\text {li }}$ Crystallographic data for the structures reported here have been deposited with the Cambridge Crystallographic Data Centre (Deposition No. CCDC613877 for $\mathrm{Cu}(\mathrm{dpa}) \mathrm{Cl}_{2}$ and $\mathrm{CCDC}-614077$ for $\left.\mathrm{Cu}(\mathrm{dpa}) \mathrm{Br}_{2}\right)$. The data can be obtained free of charge wa wnw.ccdc.cam. ac.kr/perl/catreq/catreq.cgi (or from the CCDC. 12 Union Road Cambridge CB2 lEZ. UK; Fax: +44-1223 336033; Email: depositaccdc.cam.ac.uk)

The EPR spectral measurements were carried out for powered samples at $77 \mathrm{~K}$ using an ESP-300S EPR spectrometer at the $\mathrm{X}$-band frequency. The field modulation frequency was $100 \mathrm{kHz}$ and DPPH was used as a reference.

Magnetic susceptibility data was collected from 4 to $300 \mathrm{~K}$ by the SQUID method using the Magnetic Property Measurement Sy stem (MPMS7) Quantum Design. The data was corrected for the diamagnetism of the constituent atoms 
using Pascal's constants and for the temperature-independent paramagnetism of the copper estimated to be $60^{\circ} \times 10^{-6} \mathrm{cgsu} /$ $\mathrm{Cu}$ atom. Electronic absorption spectra were recorded on a Jasco V-570 UV/Vis/NIR spectrophotometer in methanol.

\section{Results and Discussion}

Description of structure. The titled compounds consist of monomeric $\mathrm{Cu}(\mathrm{dpa}) \mathrm{X}:(\mathrm{X}=\mathrm{Cl}, \mathrm{Br})$ units that are connected through the hydrogen bonds and form one dimensional net work in the cell.

The crystallographic data and structure refunement parameters of the prepared compounds are summarized in Table 1. The selected bond distances and bond angles of these two compounds are listed in Table 2. A typical ORTEP view of $\mathrm{Cu}(\mathrm{dpa}) \mathrm{Cl}_{2}$ including the atomic numbering scheme is shown in Figure 1. The complex adopts a pentacoordinated square pyramidal geometry in which three nitrogen atoms in

Table 1. Crystallographic data for the complexes, $\mathrm{Cu}\left(\mathrm{dpa}_{\mathrm{C}} \mathrm{Cl}_{2}\right.$ and $\mathrm{Cu}(\mathrm{dpa}) \mathrm{Br}_{2}$

\begin{tabular}{|c|c|c|}
\hline & $\mathrm{Cu}(\mathrm{dpa}) \mathrm{Cl}_{2}$ & $\mathrm{Cu}(\mathrm{dpa}) \mathrm{Br}_{2}$ \\
\hline Chemical formula & $\mathrm{C}_{1:} \mathrm{H}_{1} \mathrm{Cl}_{2} \mathrm{CuN}_{3}$ & $\mathrm{C}_{12} \mathrm{H}_{13} \mathrm{Br}_{2} \mathrm{CuN}_{3}$ \\
\hline Fonmula weight (annu) & 333.69 & 422.61 \\
\hline Crystal description & blue, block & blue, block \\
\hline Crystal size (mm) & $0.23 \times 0.17 \times 0.17$ & $0.23 \times 0.20 \times 0.17$ \\
\hline Crystal system & monoclinic & monoclinic \\
\hline Space group & $\mathrm{r} 21 / 111$ & $\mathrm{P} 2 \mathrm{l} / \mathrm{m}$ \\
\hline$T(\mathrm{~K})$ & $293(2)$ & $293(2)$ \\
\hline Radiation (Mo $\operatorname{K} \alpha)(\lambda / \AA)$ & 0.71073 & 0.71073 \\
\hline \multicolumn{3}{|l|}{ Unit cell dinensions } \\
\hline$u(\AA)$ & $6.5311(6)$ & $6.7635(8)$ \\
\hline$b(\AA)$ & $13.3857(13)$ & $13.4047(11)$ \\
\hline$C(A)$ & $7.9622(16)$ & $8.2551(11)$ \\
\hline$\alpha\left(0^{\circ}\right)$ & 90.00 & 90,00 \\
\hline$\beta\left({ }^{\circ}\right)$ & $103.369(10)$ & $104.916(13)$ \\
\hline$\gamma\left({ }^{0}\right)$ & 90.00 & 9000 \\
\hline Volume $\left(\AA^{3}\right)$ & $677.22(16)$ & $723.21(14)$ \\
\hline$Z$ & 2 & 2 \\
\hline$D_{\text {salc }}\left(\mathrm{Mgmin}^{-3}\right)$ & 1.636 & 1.941 \\
\hline$\mu\left(m m^{-1}\right)$ & 1.991 & 7.020 \\
\hline$\theta$ Range $\left({ }^{\circ}\right)$ & $2.63-27.45$ & $2.55-26.00$ \\
\hline Absorption correction & $\psi$-sean & $\psi-\operatorname{scan}$ \\
\hline$T_{\max }$ & 0.7123 & 0.3001 \\
\hline$T_{\min }$ & 0.6632 & 0.2159 \\
\hline \multirow[t]{3}{*}{ Index range } & $-8 \leq h \leq 8$ & $-8 \leq h \leq 8$ \\
\hline & $0 \leq k \leq 17$ & $0 \leq k \leq 16$ \\
\hline & $0 \leq 1 \leq 10$ & $0 \leq 1 \leq 10$ \\
\hline Independent reflections & 1619 & 1491 \\
\hline observed reflections & 1203 & 756 \\
\hline Final R indices $[I>2 \sigma(I)]$ & 0.0442 & 0.0761 \\
\hline$a \mathrm{R}$ & 0.0862 & 0.1185 \\
\hline Restraints and paranneters & 0 and 91 & 1 and 91 \\
\hline Goodness-of-tit on $F^{2}$ & 1.044 & 1.017 \\
\hline$(\Delta / \rho)_{\max }$ & 1.000 & 1.000 \\
\hline$\Delta \rho_{\max }$ and $\Delta \rho_{\min }\left(\mathrm{e}^{-3}\right)$ & 0.529 and -0.337 & 1.096 and -0.703 \\
\hline
\end{tabular}

Table 2. The selected bond distances $(\AA)$ and bond angles $\left(^{\circ}\right)$ of the complexes, $\mathrm{Cu}(\mathrm{dpa}) \mathrm{Cl}_{2}$ and $\mathrm{Cu}(\mathrm{dpa}) \mathrm{Br}_{2}$

\begin{tabular}{|c|c|c|c|}
\hline \multicolumn{2}{|l|}{$\mathrm{Cu}(\mathrm{dpa}) \mathrm{Cl}_{2}$} & \multicolumn{2}{|l|}{$\mathrm{Cu}\left(\mathrm{dpa}_{1}\right) \mathrm{Br}_{2}$} \\
\hline \multicolumn{4}{|c|}{ Bond distances } \\
\hline Cul-N8 & $1.996(4)$ & Cul-N8 & $1.998(12)$ \\
\hline $\mathrm{Cu}-\mathrm{Nl}^{s}$ & $2.021(3)$ & $\mathrm{Cll}^{\prime}-\mathrm{Nl}^{\prime}$ & $2.046(8)$ \\
\hline $\mathrm{Cu}-\mathrm{Nl}$ & $2021(3)$ & $\mathrm{Cul}-\mathrm{Nl}$ & $2.046(8)$ \\
\hline $\mathrm{Cu}-\mathrm{Cll}$ & $2.22361(15)$ & Cul-Brl & $2.365(3)$ \\
\hline $\mathrm{Cu}-\mathrm{Cl} 2$ & $2.6235(14)$ & $\mathrm{Cul}-\mathrm{Br} 2$ & $2.751(2)$ \\
\hline \multicolumn{4}{|l|}{ Bond angles } \\
\hline $\mathrm{N} 8-\mathrm{C} u-\mathrm{N}]^{\prime}$ & $81.21(8)$ & $\mathrm{N} 8-\mathrm{Cul}-\mathrm{Nl}^{s}$ & $81.8(3)$ \\
\hline N8-Cll-Nl & $81.21(8)$ & N8-Cul-Nl & $81.8(3)$ \\
\hline $\mathrm{Nl}-\mathrm{Cu}-\mathrm{N} l^{\prime}$ & $161.94(17)$ & $\mathrm{Nl}-\mathrm{Cll}-\mathrm{Nl}^{s}$ & $163.5(5)$ \\
\hline $\mathrm{N} 8-\mathrm{Cll}-\mathrm{Cll}$ & $159.86(13)$ & N8-Cu-Brl & $1590(4)$ \\
\hline $\mathrm{Nl}-\mathrm{Cll}^{\prime} \mathrm{Cll}{ }^{\prime}$ & $97.54(9)$ & $\mathrm{Nl}-\mathrm{Cu}-\mathrm{Br} \mathbf{l}^{s}$ & $97.2(3)$ \\
\hline $\mathrm{Nl}-\mathrm{Cu}-\mathrm{Cll}$ & $97.54(9)$ & Nl-Cu-Brl & $97.2(3)$ \\
\hline $\mathrm{N} 8-\mathrm{Cll}-\mathrm{Cl} 2$ & $93.47(12)$ & $\mathrm{N} 8-\mathrm{Cu}-\mathrm{Br} 2$ & $93.8(4)$ \\
\hline $\mathrm{Nl}-\mathrm{Cll}-\mathrm{Cl} 2^{\prime}$ & $92.57(8)$ & $\mathrm{N} 1-\mathrm{Cu}-\mathrm{Br} 2^{s}$ & $91.7(2)$ \\
\hline $\mathrm{Nl}-\mathrm{Cu}-\mathrm{Cl} 2$ & $92.57(8)$ & $\mathrm{Nl}-\mathrm{Cll}-\mathrm{Br} 2$ & $91.7(2)$ \\
\hline $\mathrm{Cll}-\mathrm{Cu}-\mathrm{Cl} 2$ & $106.68(6)$ & $\mathrm{Br} 1-\mathrm{Cu}-\mathrm{Br} 2$ & $107.19(9)$ \\
\hline
\end{tabular}

Symmetry code: (i) $x .-1+1: 2, z$

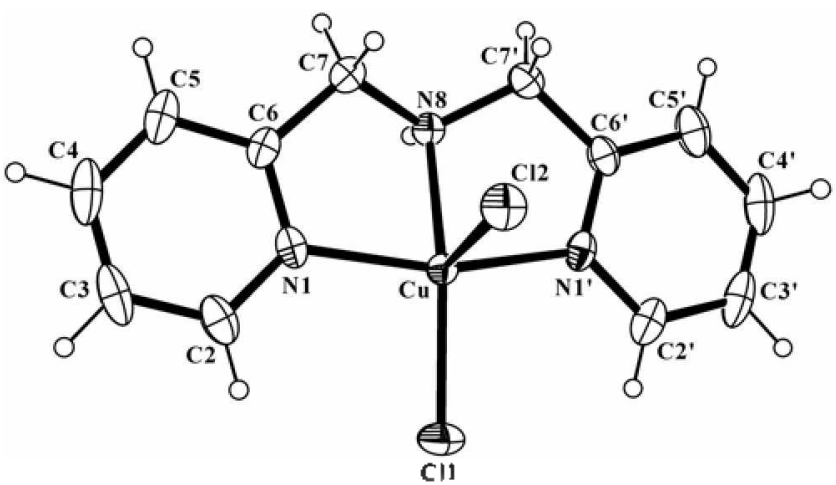

Figure 1. ORTEP diagram of $\mathrm{Cu}(\mathrm{dpa}) \mathrm{Cl}_{2}$ complex, which is shown the atom-numbering scheme (symmetry code: $x,-y+1 / 2, z$ ) and $30 \%$ probability ellipsoids.

dpa ligand $(\mathrm{Nl}, \mathrm{N} 8, \mathrm{Nl})$ and one chloride atom $(\mathrm{Cll})$ occupy the equatorial sites and the other chloride atom $(\mathrm{Cl} 2)$ possess an axial site

The coordination pattern of three nitrogen atoms in dpa ligand is a meridional fashion forming a planar rearrangement. This "planar' rearrangement is different from a 'folded' rearrangement in which one of the pyridyl nitrogens in dpa possess an axial site. and the remaining amine nitrogen and the other pyridyl nitrogen occupy equatorial sites. Therefore dpa chelates facially with the copper(II) ion in a folded rearrangement. The meridional ${ }^{? .6 .11}$ and facial ${ }^{12}$ fashions in $\mathrm{Cu}(\mathrm{II})$ complexes with dpa ligand are found for some other complexes. The meridional fashion in the present complexes leads to a regular square pyramidal coordination environment. The calculated trigonality index $\tau$ value of $\mathrm{Cu}(\mathrm{dpa}) \mathrm{Cl}_{2}$ is 0.035 indicating that $\mathrm{Cu}(\mathrm{dpa}) \mathrm{Cl}_{2}$ is almost regular square based pyramidal structure $(\tau=0$ for square pyramid and $\tau=1$ for trigonal bipyramid ${ }^{13}$ ). 
The crystal structure of $\mathrm{Cu}(\mathrm{dpa}) \mathrm{Br}_{2}$ is similar to that of $\mathrm{Cu}(\mathrm{dpa}) \mathrm{Cl}_{2}$ with the calculated $\tau$ value of 0.075 . The trigonal distortion of $\mathrm{Cu}(\mathrm{dpa}) \mathrm{Br}$ = is larger than that of $\mathrm{Cu}(\mathrm{dpa}) \mathrm{Cl}_{2}$. This is probably due to the rather steric hindrances of the larger bromide ion.

The monomeric structure of $\mathrm{Cu}(\mathrm{dpa}) \mathrm{Cl}_{2}$ were reported by Choi $e t a l^{7}$ and by Niclas et $a l^{8}$ Their crystallographic data were unsignificantly different from our work except the unit cell dimensions [ $($ a. b. $c, \beta$ and $Z) .(8.155 \AA, 12.560 \AA$. $12.817 \AA .91 .64^{\circ}$ and 4 by Choi). (6.5320 A. 13.2558 $\AA$. $15.4821 \AA .98 .98^{\circ}$ and 4 by Niclas). (6.5311 $\AA, 13.3857 \AA$. $7.9922 \AA, 103.37^{\circ}$ and 2 by this work)]. The literature data exhibited more trigonally distorted structure than our data with $\tau=0.129$ (by Choi) or $\tau=0.05$ (by Niclas). The differences from our results are probably due to the synthetic method and/or the crystallization conditions.

However, both of the reported data did not show the packing diagram of $\mathrm{Cu}(\mathrm{dpa}) \mathrm{Cl}_{2}$ in the cell. Figure 2 shows a molecular packing diagran typically for $\mathrm{Cu}(\mathrm{dpa}) \mathrm{Cl}_{2}$ in solid. Intermolecular hydrogen bonds are shown with short dashed lines. Table 3 shows the bond distances and bond angles of hydrogen bond for $\mathrm{Cu}(\mathrm{dpa}) \mathrm{Cl}_{2}$ and $\mathrm{Cu}(\mathrm{dpa}) \mathrm{Br}_{\Sigma}$. The results imply that there is a hydrogen bond formation between the hydrogen atom in N8-H in the dpa ligand and the adjacent axial chloride [Cl2] ions. The $\mathrm{Cu}(\mathrm{dpa}) \mathrm{Cl}_{2}$ molecules are held together in one dimensional network through these hydrogen bondings. The $\mathrm{Cu}(\mathrm{dpa}) \mathrm{Br}_{2}$ complex shows a similar hydro-

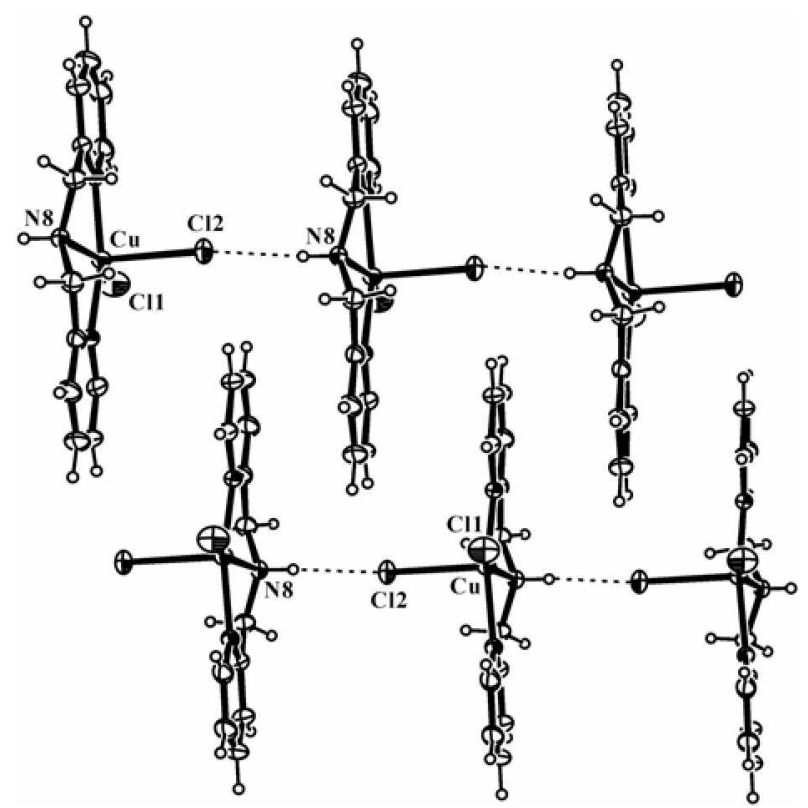

Figure 2. A molecular packing diagram of $\mathrm{Cu}(\mathrm{dpa}) \mathrm{Cl}_{2}$. Intermolecular hydrogen bonds are shown with short-dashed lines.

Table 3. The hydrogen bond distances $(A)$ and bond angle $(")$ of the complexes, $\mathrm{Cu}(\mathrm{dpa}) \mathrm{Cl}_{2}$ and $\mathrm{Cu}(\mathrm{dpa}) \mathrm{Br}_{2}$

\begin{tabular}{lccccl}
\hline & $\mathrm{D}-\mathrm{H} \cdots \mathrm{A}$ & $\mathrm{d}(\mathrm{D}-\mathrm{H})$ & $\mathrm{d}(\mathrm{H} \cdots \mathrm{A}) \mathrm{d}(\mathrm{D} \cdots \mathrm{A})$ & $\angle(\mathrm{DHA})$ \\
\hline $\mathrm{Cu}(\mathrm{dpa}) \mathrm{Cl}_{2}$ & $\mathrm{~N} 8-\mathrm{H} 8 \cdots \mathrm{Cl} 2^{i \prime}$ & $0.85(5)$ & $2.35(5)$ & $3.176(4)$ & $166(5)$ \\
$\mathrm{Cu}(\mathrm{dpa}) \mathrm{Br}_{2}$ & $\mathrm{~N} 8-\mathrm{H} 8 \cdots \mathrm{Br} 2^{i j}$ & $0.85(2)$ & $2.47(5)$ & $3.273(11)$ & $160(13)$ \\
\hline
\end{tabular}

gen bonded network in the crystal.

This hydrogen bond can affect the $\mathrm{Cu}-\mathrm{Cl}$ and $\mathrm{Cu}-\mathrm{N}$ bond lengths in $\mathrm{Cu}(\mathrm{dpa}) \mathrm{Cl}_{2}$. The distance of $\mathrm{Cu}-\mathrm{Cl}_{\mathrm{c} \times \mathrm{j} \text { il }}$ is longer than that of $\mathrm{Cu}-\mathrm{Cl}_{\text {equatoral }}$ by $0.4 \AA$ in the present complex. This increase in $\mathrm{Cu}-\mathrm{Cl}_{\mathrm{c} \mid \mathrm{i} \text { ial }}$ is resulted from a reduction of electron density on the axial chloride ions due to a formation of the intermolecular hydrogen bonds between the axial chloride ions and the amine hydrogens. ${ }^{14}$ Particularly notable is the $\mathrm{Cu}-\mathrm{N}$ bond length in $\mathrm{Cu}(\mathrm{dpa}) \mathrm{Cl}_{2}$. Choi $\mathrm{et} \mathrm{al}^{7}$ reported that $\mathrm{Cu}-\mathrm{N}_{\text {annne }}(2.075 \mathrm{~A})$ was longer than $\mathrm{Cu}$ $\mathrm{N}_{\text {pyrdune }}\left(2.006 \AA\right.$ ) bond length in monomeric $\mathrm{Cu}(\mathrm{dpa}) \mathrm{Cl}_{2}$. They proposed that this differences were on account of the $\mathrm{sp}^{3}$ hybridization of the coordinated tertiary nitrogen atom in $\mathrm{Cu}-\mathrm{N}_{\text {anune. }}$. Such a result was also reported in copper(II) complexes with dpa-derived ligands. ${ }^{15}$ But we examined the controvertible result that $\mathrm{Cu}-\mathrm{N}_{\text {anune }}(1.996 \mathrm{~A})$ is shorter than $\mathrm{Cu}-\mathrm{N}_{\text {pyrdine }}\left(2.021 \AA\right.$ ) bond length in the present $\mathrm{Cu}(\mathrm{dpa}) \mathrm{Cl}_{2}$ complex. Palaniandavar et $a .^{16}$ reported the structure of $\left[\mathrm{Cu}(\mathrm{dpa})_{2}\right] \mathrm{BF}_{4}$, and they examined the pentacoordinated square pyramidal $\left[\mathrm{Cu}(\mathrm{dpa})_{2}\right]^{\hat{2}^{+}}$as well as hexacoordinated octahedral $\left[\mathrm{Cu}(\mathrm{dpa})_{2}\right]^{\hat{i}^{+}}$cation in the same cell. In the square pyramidal $\left[\mathrm{Cu}(\mathrm{dpa})_{2}\right]^{2+}$ cation, one dpa coordinated with copper(II) ion meridionally in the equatorial site and the other dpa functioned as a bidentate ligand with one of the pyridine nitrogens in the equatorial site and the amine nitrogen in the axial position. The shorter $\mathrm{Cu}-\mathrm{N}_{\text {annme }}$ bond $\left(\mathrm{Cu}-\mathrm{N}_{\text {pyrdduse }}=2.044,2.027 \AA\right.$ and $\left.\mathrm{Cu}-\mathrm{N}_{\text {annuse }}=1.9957 \AA\right)$ in the equatorial site in a square pyranidal $\left[\mathrm{Cu}(\mathrm{dpa})_{2}\right]^{\hat{2}^{-}}$cation is a consequence of the hydrogen bond formation between the uncoordinated pyridine nitrogen in a bidentate dpa ligand and the hydrogen atom in the secondary amino group in an equatorial site. Therefore we suggest that the shorter $\mathrm{Cu}-\mathrm{N}_{\text {anune }}$ than $\mathrm{Cu}-\mathrm{N}_{\text {pyridime }}$ bond can be elucidated from the fact that the anine hydrogens took part in the formation of the hydrogen bond resulting in the stronger bond formation between the amine nitrogen and copper(II) ion in $\mathrm{Cu}(\mathrm{dpa}) \mathrm{Cl}_{2}$ crystal.

Magnetic and optical properties. The magnetic susceptibilities of powdered $\mathrm{Cu}(\mathrm{dpa}) \mathrm{Cl}_{2}$ sample were collected as a function of temperatures in the range of $4 \mathrm{~K}$ to $300 \mathrm{~K}$ typically in Figure 3. The magnetic susceptibility data increased as decreasing the temperatures and no maximum in the susceptibilities was observed exhibiting a paramagnetic behavior with a Curie-Weiss tail. The magnetic susceptibility data was fit well to the Curie-Weiss law. $\chi_{\mathrm{m}}=\mathrm{C}$ $(\mathrm{T}-\theta)$ as shown in Figure 3. indicating that there is no magnetic interactions between the copper(II) ions. A linear regression results in a Curie-Weiss temperature $\theta=2.36 \mathrm{~K}$ and a Curie constant $C=0.42 \mathrm{~cm}^{2} \mathrm{~K} \mathrm{~mol}^{-1}$ for $\mathrm{Cu}(\mathrm{dpa}) \mathrm{Cl}_{2}$, and $\theta=-0.93 \mathrm{~K}$ and $C=0.44 \mathrm{~cm}^{3} \mathrm{~K} \mathrm{~mol}^{-1}$ for $\mathrm{Cu}(\mathrm{dpa}) \mathrm{Br}_{2}$. The effective magnetic moments were calculated from the equation. $\mu_{\text {etf }}=2.828\left(\chi_{\mathrm{m}} \times \mathrm{T}\right)^{1 / 2}$. The values of calculated magnetic moment at roon temperature are 1.82 B.M. and $1.87 \mathrm{~B} . \mathrm{M}$. for $\mathrm{Cu}(\mathrm{dpa}) \mathrm{Cl}_{2}$ and $\mathrm{Cu}(\mathrm{dpa}) \mathrm{Br}_{2}$ respectively. The magnetic moments are almost constant in the experimental temperature which is a typical feature for isolated copper(II) complexes with one unpaired electron. This result is expected 


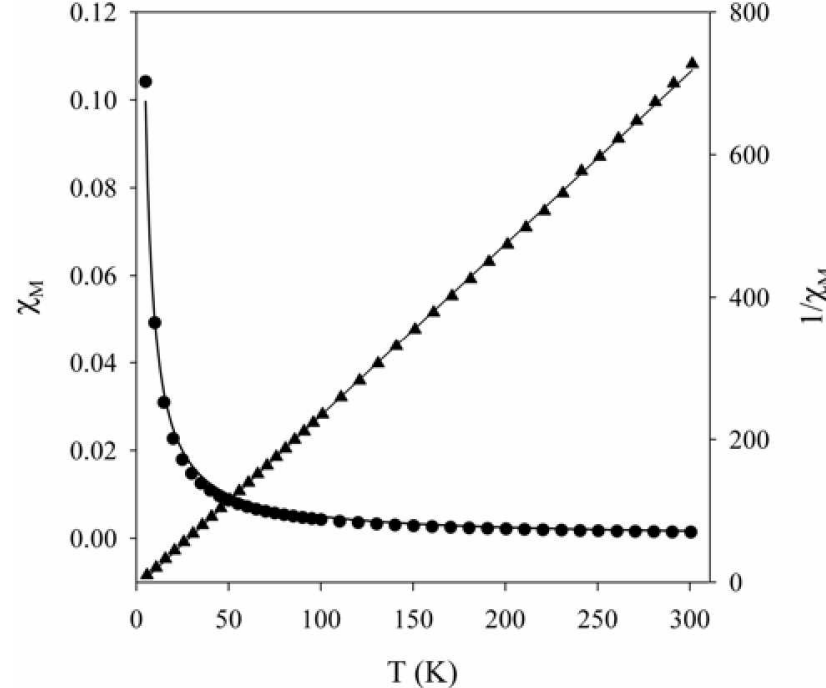

Figure 3. A plot of magnetic susceptibility (left scale, circle shape) and Curie-Weiss fit of $\chi^{\prime}$ (right scale, triangle shape) vs. temperature in the region of $4-300 \mathrm{~K}$ for $\mathrm{Cu}(\mathrm{dpa}) \mathrm{Cl}_{2}$.

from the fact that the nearest distances between $\mathrm{Cl} \cdots \mathrm{Cu}$ [6.531 $\AA$ and $6.764 \AA$ for $\mathrm{Cu}(\mathrm{dpa}) \mathrm{Cl}_{2}$ and $\mathrm{Cu}(\mathrm{dpa}) \mathrm{Br}$. respectively] are much longer than the sum of the corresponding van der Waals radii, and this distance is considered to be too long to allow any significant magnetic interactions between the units.

EPR spectra of the prepared compounds were obtained for powdered solid at $77 \mathrm{~K}$. The EPR line shapes for both compounds exhibit a resolution of parallel $\left(\mathrm{g}_{\mid}\right)$and perpendicular $\left(\mathrm{g}_{-}\right)$components with an axial synmetry $\left[\mathrm{g}_{\mid}=\right.$ 2.244. $\mathrm{g}_{-}=2.060$ for $\mathrm{Cu}(\mathrm{dpa}) \mathrm{Cl}_{2}$ and $\mathrm{g}_{\|}=2.218, \mathrm{~g}_{-}=2.078$ for $\mathrm{Cu}(\mathrm{dpa}) \mathrm{Br}$ :]. No observation of a well-defined hyperfine splitting in both compounds is likely due to the hydrogen bonding formed between N8-H in the dpa ligand and the adjacent terminal chloride [Cl2]. EPR spectra are consistent with a pentacoordinated square pyramidal structure with the unpaired electron in the $d_{x}=-y$ : orbital.

The UV-Vis. spectra in methanol solution shows an asymmetric broad peak occurring at around $670 \mathrm{~nm}$ and a intraligand $\pi \rightarrow \pi$ transitions with a maximum at $299 \mathrm{~nm}$ for both compounds. The absorption maximum at around $670 \mathrm{~nm}$ is typical of the spectra for the copper(II) complexes with a pentacoordinated square pyramidal geometry that generally exhibit due to the transition of $d_{\mathrm{z} z}, d_{\mathrm{yz}} \rightarrow \mathrm{d}_{\mathrm{x}}=-\mathrm{y}_{\mathrm{z}}$. being consistent with its stereochemistry. ${ }^{17}$
In conclusion. the tridentate dpa ligand coordinated with copper(II) halide in a meridional fashion. which leaded to a square pyramidal geometry around copper(II) ion. The prepared complexes conducted like isolated descriptive monomers in a magnetic behavior, even if the complexes held together through hydrogen bonds forming one-dimensional network in the solid state. The hydrogen bond can affect the copper-nitrogen bond strength resulting in a shorter $\mathrm{Cu}$ $\mathrm{N}_{\text {cumne }}$ than $\mathrm{Cul}-\mathrm{N}_{\text {pysndne }}$ bond length, which is contrary to the reported data. ${ }^{7}$

Acknowledgement. This work was supported by the Ministry of Information and Communication. Korea. under the Information Technology Research Center (ITRC) Support Program.

\section{References}

1. Storr, T:; Sugai, Y; Barta, C. A.: Mikata. Y.: Adam, M. J.; Yano. S.; Orvig, C. Inorg Chem 2005 t, 2698.

2. Mikata. Y: Sugai. Y: Yano. S. Hhorg Chem. 2004. +3. 4778.

3. Mikata. Y: Sugai. Y: Obata. M.: Harada. M.: Yano. S. Inorg. Chent 2006. 45.1543.

4. Ojida. A.: Mito-oka. Y.: Inoule. M.-A.: Hamachi. I. J. Ant Chent. Soc. 2002, $12 t, 6258$

5. Ojida, A.: Mito-oha, Y.: Sada K.: Hamachi, I. J. Am. Chem. Soc. 2004. 126,2454 .

6. Kirin. S. I.: Dubon. P.: Weyhermuller. T.: Bill. E.: Metzler-Nolte. N. Inorg. Chem. 2005.4 . 5405.

7. Choi. K.-Y.: Ryu. H.: Sung. N. D.: Suh. M. J. Chent Chstallogr 2003. 33,947 .

8. Niklas. N.: Heinemann, F. W.: Hampel. F.: Clark. T.: Alsfasser, R Inorg. Chem 2004, 43,4663 .

9. Sheldrick. G. M. SHELIS97 and SHEL1Z97. Program for the Refinement of Chystal Structures. Utuversity of Gottingen: Gemany. 1997.

10. Farrugia, L. J. J. Appl. Const. 1997.30,565.

11. Murakami. T: Hatakeyama, S.: Igarashi, S.: Yukawa, Y. Inorg. Chim teta 2000. $310,96$.

12. Murakami. T.: Orihashi. Z.: Kikuchi. Y.: Igarashi. S.: Yukawa. Y. Inorg. Chint .Acta 2000. 303. 148.

13. Addison. A. W.: Rao. T. N.: Reedjik. J.: van Riyn. J.: Verschoor. G. C.J. Chem. Soc. Dalton Trans. 1984, 1349

14. Kang. S. K.: Kim. H. S.: Kim. Y.-I. Bull Korean Chem. Soc. 2006. 27,1877

15. Choi. K.-Y.: Jeon. Y.-M.: Lee. K.-C.: Choi. S.-N. Transition Met Chen. 2004. 29.405.

16. Palaniandavar. M.: Butcher. R. T.: Addison. A. W. Inorg. Chent 1996. 35,467

17. Du. M; Guo. Y.-M: Chen. S.-T: Bu, X.-H; Ribas. J. Inorg Chim. Acta 2003. 3+6, 207 